\title{
Relationships between Websterite Xenolith and Host Basanite (Pipe Bele, Khakasia, Russia): Evidence from Fluid and Silicate-Melt Inclusions in Minerals.
}

\author{
Sharygin, V.V. ${ }^{1}$, Golovin, A.V. ${ }^{2}$, Smirnov, S.Z. ${ }^{1}$, and Malkovets, V.G. ${ }^{1}$
}

1. Institute of Mineralogy and Petrography, 630090 Novosibirsk, Russia.

2. Novosibirsk State University, 630090 Novosibirsk, Russia.

E-mails: sharygin@uiggm.nsc.ru, smirnov@uiggm.nsc.ru, vomal@uiggm.nsc.ru

The Bele pipe is one of typical diatremes of Khakasia. It is composed of basanites and their breccias. Basanites contain numerous crustal (granulites) and mantle (lherzolites, pyroxenites) xenoliths up to $20 \mathrm{~cm}$ in size. The isotopic dating performed for zircons and basanites from the Bele pipe has yielded ${ }^{206} \mathrm{~Pb} /{ }^{238} \mathrm{U}$ age of zircon as $77.9 \mathrm{Ma}$ (Ashchepkov et al., 1995) and ${ }^{40} \mathrm{Ar}{ }^{39} \mathrm{Ar}$ age of rock as $79 \pm 2 \mathrm{Ma}$ (recent data).

Basanite specimen with a websterite xenolith has been studied by fluid inclusions. Fluid and silicate-melt inclusions have been observed in minerals from both websterite xenolith and host basanite, and also in minerals of interstitial mass of websterite. The host basanite contains olivine $(\mathrm{Mg \#}-0.8)$ and Ti-augite $(\mathrm{Mg \#}-0.74)$ phenocrysts, and groundmass consisting of plagioclase $\left(\mathrm{An}_{60} \mathrm{Ab}_{40}\right)$, augite, magnetite, apatite, ilmenite and rarely altered nepheline. The websterite xenolith (up to $5 \mathrm{~cm}$ in size) are composed of subcalcic augite $(\mathrm{Mg} \#-0.83-0.86)$, orthopyroxene (Mg\# $0.83-0.84$ ), and rarely $\mathrm{Al}$-spinel. The intergranular mass in the xenolith contains olivine, $\mathrm{Al}$-spinel, $\mathrm{K}$ $\mathrm{Na}$ feldspar and, rarely, plagioclase and sulfides, while the chemistry of the interstitial minerals are practically similar to that of basanite minerals.

\section{Websterite}

Two generations of inclusions can be recognized in minerals of websterite xenolith from the Bele pipe.

First generation ("early", "primary" high-density $\mathrm{CO}_{2}$ inclusions).

They were found in orthopyroxene of the xenolith. The sizes of inclusions are 15-25 $\mu \mathrm{m}$, the shape is isometric, semi-faceted, rarely rounded, sub-spherical. The following observations suggest their possible primary nature: (1) inclusions are not confined to any healed fractures or cleavage of the host orthopyroxene; (2) they are not associated with silicate-melt and sulfide inclusions (unlike secondary fluid inclusions). All of these inclusions show evidence of partial decrepitation (haloes around them or microfractures extended from them). Melting temperatures for these fluid inclusions are $-57.3^{\circ} \mathrm{C}$, which indicates that the trapped fluid is $\mathrm{CO}_{2}$ with minor amounts of other volatiles. The $\mathrm{H}_{2} \mathrm{O}$ has not been found during cryometric study. The homogenization into liquid phase for a less leaked inclusion occurred at $-25^{\circ} \mathrm{C}$, that corresponds to $1.055 \mathrm{~g} / \mathrm{cm}^{3}$ density calculated on the basis of the $\mathrm{CO}_{2}$ vapor-liquid equilibrium (Roedder, 1984). Raman spectroscopy shows that fluid of this inclusion is composed of $\mathrm{CO}_{2}\left(95\right.$ mole \%) and $\mathrm{N}_{2}(5 \mathrm{~mole} \%)$. Hydrocarbons were not detected.

Unfortunately, the direct data on temperature of "primary» fluid inclusion trapping are absent. However, temperature of last mineral equilibrium for the studied xenolith may be considered as minimum temperature of inclusion trapping. Its estimation calculated on the basis of two-pyroxene thermometer (Brey and Köhler, 1990) is $940^{\circ} \mathrm{C}$. Using the above data on the density and composition of $\mathrm{CO}_{2}$-rich fluid, FLINCOR program and the data on the $\mathrm{CO}_{2}-\mathrm{N}_{2}$ system (Van den Kerkhof, 1988), the trapping pressure for "primary» inclusion with the highest density can be estimated as exceeding $8.5 \mathrm{~kb}$ at $940^{\circ} \mathrm{C}$. This value represent the lower limit for entrapment pressure, because the fluid inclusion has been partly leaked. Taking into account possible secondary nature of those inclusions and basanite liquid as more real influence agent on xenolith (approximately $1200^{\circ} \mathrm{C}$ ), 
trapping of the «primary» fluid inclusion may has occurred at even higher PT-parameters $(>10 \mathrm{~kb}$, $>1200^{\circ} \mathrm{C}$ ), which means the upper mantle setting. The similar $\mathrm{CO}_{2}$-rich inclusions have been also found in mantle xenoliths from different suites (Schiano and Clocchiatti, 1994; Szabo and Bodnar, 1996; Varela et al., 1997).

\section{Second generation (secondary silicate-melt, fluid and sulfide inclusions).}

They have been observed mainly in clinopyroxene. The sizes of the inclusions vary from 2 to $50 \mu \mathrm{m}$. Melt and fluid inclusions are generally confined to the same healed fissures in the host clinopyroxene. This suggests their syngenetic nature. These inclusions are associated with polysulfide globules (pyrrhotite + pentlandite + chalcopyrite) and single crystalline inclusions. The latter are alligned along cleavage fissures of the host and represented by $\mathrm{Al}$-spinel, olivine (Mg\# - 0.8), and plagioclase $\left(\mathrm{An}_{83} \mathrm{Ab} \mathrm{b}_{17}\right)$. Phase composition of silicate-melt inclusions is glass + gas \pm trapped/daughter crystals (Al-spinel, clinopyroxene, apatite). The homogenization of melt inclusions occurred at $1100-1200^{\circ} \mathrm{C}$. Melting temperatures for fluid inclusions are $-57.4-60.0^{\circ} \mathrm{C}$. Their homogenization into liquid phase occurred at $+25^{\circ} \mathrm{C}$. Raman spectroscopy shows that fluid of these inclusions are composed of $\mathrm{CO}_{2}\left(93\right.$ mole \%) and $\mathrm{N}_{2}(7$ mole \%). The trapping pressures for the secondary inclusions can be estimated as $2.4-2.6 \mathrm{~kb}$ at $1100-1200^{\circ} \mathrm{C}$.

\section{Interstitial mass in websterite xenolith}

Primary silicate-melt inclusions have been observed in olivine grains only. Their phase composition is glass + gas \pm daughter crystals. Homogenization occurred at $>1100^{\circ} \mathrm{C}$.

\section{Basanite}

Primary silicate-melt inclusions $(10-30 \mu \mathrm{m})$ have been found in olivine and zoned Ti-augite phenocrysts. Phase composition is glass + gas + daughter crystals, represented by clinopyroxene, apatite, and magnetite. In Ti-augite phenocrysts the melt inclusions are generally confined to the outer zones and associated with independent crystals of plagioclase and magnetite. Homogenization of these inclusions occurred at $1130-1160^{\circ} \mathrm{C}$. The data are in the same temperature range as those for melt inclusions in websterite clinopyroxene.

\section{Chemistry of inclusion glasses in minerals of websterite and basanite}

Glasses of heated inclusions from websterite clinopyroxene drastically differ in major element composition from the xenoliths. They are enriched in $\mathrm{SiO}_{2}$ (49-55 wt.\%), $\mathrm{Al}_{2} \mathrm{O}_{3}$ (14-19 wt.\%), $\mathrm{TiO}_{2}$ (0.4-1 wt.\%), $\mathrm{CaO}$ (5-10 wt.\%), alkalis (2-6.5 wt.\%), $\mathrm{P}_{2} \mathrm{O}_{5}$ (up to 1.4 wt.\%), $\mathrm{Cl}$ (up to 0.2 wt.\%) and depleted in $\mathrm{MgO}$ (3.5-8.3 wt.\%), $\mathrm{FeO}$ (up to $8 \mathrm{wt} \%$ ). In general, these glasses have compositions practically similar to the host basanites and glasses of heated inclusions in basanite clinopyroxene, differing from them in higher $\mathrm{SiO}_{2}$ only (see Figure).

Residual glasses of silicate-melt inclusions in clinopyroxene from both websterite and basanite have similar compositions. Unlike glasses of heated inclusions, they are enriched in $\mathrm{SiO}_{2}$ (57-68 wt.\%), $\mathrm{Al}_{2} \mathrm{O}_{3}$ (23-26 wt.\%), $\mathrm{Cl}$ (up to $0.9 \mathrm{wt} . \%$ ), alkalis (up to $8.5 \mathrm{wt} . \%$ ) and essentially depleted in $\mathrm{FeO}$ (down to 0.4 wt.\%), $\mathrm{MgO}(0.06-0.5$ wt.\%), $\mathrm{CaO}(0.3-1.3$ wt.\%). Melt inclusions in olivine from basanite and interstitial mass of the xenolith contain higher $\mathrm{SiO}_{2}$ (up to $71 \mathrm{wt} \%$ ) and lower $\mathrm{Al}_{2} \mathrm{O}_{3}$ (18-20 wt.\%). The wide variations in the major element contents seem to be related to the composition and the quantity of phases which formed inside the inclusions. Chemical composition of the secondary melt inclusions in clinopyroxene of the Bele websterite approaches those of secondary melt inclusions in mantle xenolith minerals from different occurrences of the world (Schiano and Clocchiatti, 1994; Szabo et al., 1996; etc.).

Thus, in terms of compositions there are no principal differences between glasses of silicatemelt inclusions in minerals from both the websterite and the host basanite of the Bele pipe. This 
pertains to both heated and unheated inclusions. On the basis of the above data, we suggest that secondary melt inclusions in websterite clinopyroxenes is the result of the infiltration of basanite liquid into xenolith at $\mathrm{P}>2.6 \mathrm{~kb}$ and $\mathrm{T}>1200^{\circ} \mathrm{C}$. The broad compositional variations for heated glasses of these inclusions may be attributed to the partial reaction between the initial basanite melt and clinopyroxene of the xenolith. Thus, two P-T-stages of influence of basanitic melt on websterite xenolith may be divided: 1) $>>8.5 \mathrm{~kb}$ and $>950^{\circ} \mathrm{C}$ - upper mantle-low crust conditions; 2) 2.4-2.6 kb and $1100-1200^{\circ} \mathrm{C}$ - middle-shallow crust conditions. Our conclusions are in contrast with those of Schiano and Clocchiatti (1994). According to these authors, secondary silicate-melt inclusions in minerals of sub-continental and sub-oceanic mantle xenoliths represent small-volume metasomatic melts which migrate in the upper mantle.

This study was supported by the Russian Foundation of Basic Research (grant № 97-0565309) and Siberian Branch of RAS (grant for young scientists).
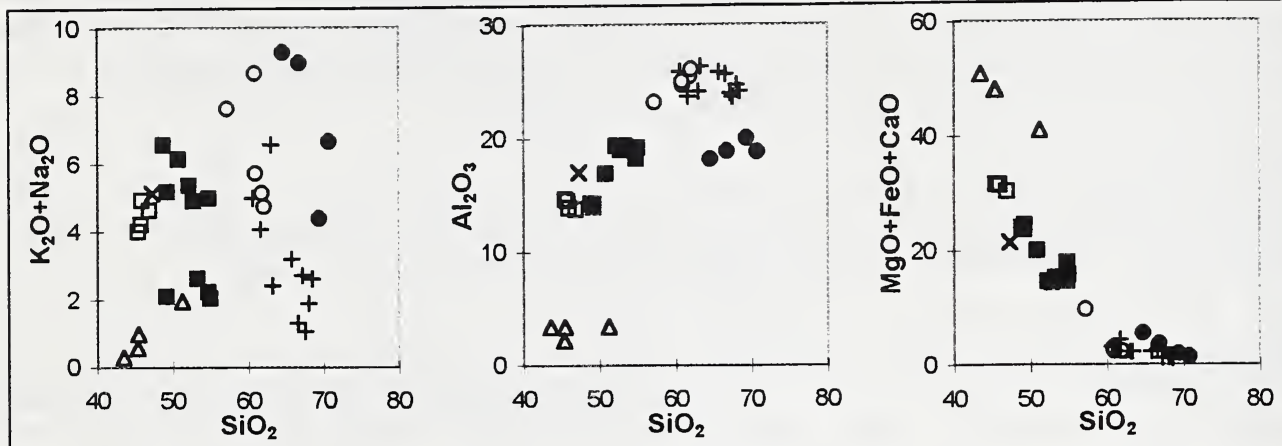

$\triangle \quad$ xenoliths of the Bele pipe (Ashchepkov et al, 1995);

basanites of the Bele pipe (Ashchepkov et al, 1995);

glasses of heated inclisions in clinopyroxene of websterite;

$+\quad$ residual glasses of unheated inclusions in clinopyroxene of websterite;

* glass of heated inclisions in clinopyroxene of basanite;

residual glasses of unheated inclusions in clinopyroxene of basanite;

- residual glasses of unheated inclusions in olivine of basanite and in interstitial olivine of websterite.

\section{References}

Ashchepkov, I.V.. Kepezhinskas, V.V., Malkovets, V.G., Ovchinnikov, Yu.I., 1995, Mantle xenoliths from the MesoCenozoic volcanic pipes of Khakassia: Field guide book of $6^{\text {th }}$ International Kimberlite Conference, Novosibirsk. $39 \mathrm{p}$. Brey, G.P. and Köhler, T., 1990, Geothermobarometry in four phases lherzolites. II: new thermobarometers and practical assessment of using thermobarometers: J. Petrol., 31, p. 1353-1378.

Schiano, P. and Clocchiatti, R., 1994, Worldwide occurrence of silica-rich melts in sub-continental and sub-oceanic mantle minerals: Nature, 368, p. 621-624.

Szabo. Cs. and Bodnar, R.J., 1996, Changing magma ascent rates in the Nógrád-Gömör volcanic field Northern Hungary/Southern Slovakia: Evidence from $\mathrm{CO}_{2}$-rich fluid inclusions in metasomatized upper mantle xenoliths: Petrologiva, 4(3), p. 240-249.

Szabo, Cs., Bodnar, R.J. and Sobolev, A.V., 1996, Metasomatism associated with subduction-related, volatile-rich silicate melt in the upper mantle beneath the Nógrád-Gömör volcanic field Northern Hungary/Southern Slovakia: Evidence from silicate-melt inclusions: Eur. J. Mineral., 8, p. 881-899.

Roedder. E.. 1984, Fluid inclusions in minerals: Rev.Mineral., 12, p. 109-148.

Van den Kerkhof. A.M.. 1988, The system $\mathrm{CO}_{2}-\mathrm{CH}_{4}-\mathrm{N}_{2}$ in fluid inclusions: theoretical modelling and geological applications: Free University Press, Amsterdam, 206 pp.

Varela. M.E., Bjerg, E.A., Clocchiatti, R., Labudia, C.H. and Kurat, G., 1997, Fluid inclusions in upper mantle xenoliths from Northern Patagonia Argentina: evidence for an upper mantle diapir: Mineral. Petrol., 60 (3-4). 